\title{
Perceptions towards E-learning in Times of COVID-19 Lockdown Phase in the Tertiary Education
}

\section{Dr. Hanan Ahmed El-Sayyed Sanad}

English Language Teacher

Abstract

OVID-19 pandemic had a huge effect on people's lives and lifestyles all over the world since its first spread in China between late 2019 and early 2020. The educational systems in all countries were among the first concerns that had to be dealt with to complete the academic year for students. The only and rapid solution was the use of e-learning. Thus, The advent of online learning (e-learning) has also encouraged the widespread acceptance of learner-centric education and other improvements in education practices. The present study aimed at exploring the perceptions of students and teachers on the use of e-learning during the COVID-19 lockdown phase. Participants represented samples of the students from various Egyptian private and governmental universities that depended on e-learning in completing the courses and evaluating students. Many challenges and difficulties faced different universities as it was the first time for some of them to depend on e-learning completely. Instruments included a teachers' reflection survey and a students' reflection survey. They were used to determine the perception of the respondents. Findings showed general agreement among teachers and students on using e-learning during and after the lockdown phase, despite some challenges.

Keywords: e-learning, virtual teaching, online education, COVID-19,pandemic, COVID-19 epidemic

\section{Introduction}

Using online tools to automate learning is the latest trend in the professional training and development market and has been identified as the e-learning revolution. In today's organizations, most e-learning is asynchronous. Asynchronous e-learning refers to 'pre-recorded' e-learning that is accessible to workers at any time of the day, likely from every place (Rosenberg, 2001). Less popular is 
synchronous e-learning or e-learning that is 'real' and demands that all learners be in front of their computers simultaneously (Welsh et al., 2003). The COVID -19 outbreak had a very important influence on worldwide education systems. After the beginning of COVID-19 pandemic at the beginning of 2020, Egypt's educational system has faced a significant challenge concerning the form of curricula being provided to learners. Our education system relies on conventional educational settings, where the teacher uses books, chalkboards as a teaching aid, and our new classroom education, where the classrooms are fitted with smart boards, and interactive digital devices (Basilaia \& Kvavadze, 2020). With the advent of the first case of the COVID-19 coronavirus in Egypt, the educational scenario has changed, particularly after the quarantine was introduced. There was a growing need to shift from face-to-face to teaching online. Since the pandemic, numerous countries around the world have adopted different approaches to maintaining the same level of education. In at least 96 nations, electronic archives, television shows, guides, tools, video tutorials, multimedia channels have been launched. (Basilaia \& Kvavadze, 2020). The attitudes of students in tertiary education towards e-learning can be influenced by distinctive individual elements. Previous technical experience, technology acceptance, and individual style of learning are among the factors that affect perceptions for e-learning (Keller \& Cernerud,2002). Throughout this study, the researcher aimed at investigating the expectations and attitudes toward its use by both the students and the teachers.

\section{Literature review}

\section{Definition of e-learning}

In education, the term e-learning has been commonly used since the mid-1990s. The concept of e-learning however was not explicitly accepted (Lee et al. ,2009). Holmes \& Gardner (2006, p14) defined e-learning as " online access 
to learning resources, anywhere and anytime". Clark \& Mayer (2016, p 7) defined e-learning as "instruction delivered on a digital device that is intended to support learning.". They differentiated between the major types of e-learning design; asynchronous e-learning, led by the instructor and designed for self-study and synchronous elearning. The concept has three components : 'what, why, and how ' denoting the content, the digital device, and how learning objectives are achieved. Mayes \& Freitas (2004) defined e-learning as learning enhanced by technology that focuses on the use of technology to support and enhance the learning experience.

Afifi \& Alamri (2014). Defined e-Learning as a learning style that focused on the learner's needs and abilities and the use of electronic media on the internet that is used synchronously or asynchronously to provide e-content (readings, lectures, discussions, assessments, and tests) and to control it, whether indoor or outdoor, through a university platform, to promote and encourage learning at any time..'.

\section{Features and Benefits:}

Clark \& Mayer (2016, p 8) listed features of forms of elearning as follows:

- an electronic form that is used to transmit information on external or internal places.

- The material that meets the purpose of learning.

- Media features, such as content provisioning tools.

- Methods of instruction that improve learning.

- (synchronous e-learning) or (asynchronous elearning).

- virtual rooms or discussion boards.

According to Clark \& Mayer (2016) and Welsh et al (2003), organizations required e-learning to; a) save time for preparation and travel related to traditional face-to-face education; provided that e-learning develops awareness and 
skills that help achieve desired job goals. b) have standardized instruction across several locations.. c) fast delivering of training to many people. d) improve learner comfort. e) handle the rise in the number of knowledge workers need to know. F) track learner behaviors and subject mastery. In the following points they outlined five expectations for e-learning:

1. Customized Training: Asynchronous self-study elearning can tailor learning to each learner's specific needs. Customized training means styling content, methods of instruction, and recommendations according to the needs of students.

2. Engagement in Learning: There are two types of commitments: cognitive and psychological. Through attention to actions, we mean every direct action that a learner takes during the process of instruction. By psychological engagement, we mean cognitive content processing in ways that lead to the acquisition of new knowledge and competencies.

3. Multimedia: You could use a mixture of multimedia in e-learning to express

the content and help the learner develop applicable infor mation and skills.

4. expertise enhancement By Scenarios: Nevertheless, elearning provides opportunities to delude trainees into career real settings enabling them to solve difficult problems or fulfill tasks in a few moments that would take a long time to complete in the real world.

5. Learning Through gamification: The introduction of games as a means of interaction, known as gamification, is an evolving trend in workplace education. Gamification aims to offer inspiring, engaging, and successful learning experiences. Mayer (2014) reports the following features of games: (1) virtual structures based on rules, (2) receptive to the player, (3) demanding, (4) cumulative, allowing 
evaluation of progress towards goals, and (5) encouraging, providing an aesthetic value to the learner. Carliner \& Shank (2016 ) added to the advantages of e-learning, organizations that minimize costs by class eliminationrelated travel costs as well as the cost of distributing training programs. Thus, e-learning will deliver costeffective, just-in-time, customized mobile learning. This view agreed with many others such as Hall (2000), Walker (2002), Rochester (2002), and Robbins ( 2002).

\section{Pitfalls of e-Learning}

The main strengths of E-learning are a double-edged sword, as there are some drawbacks to be considered: (Carliner \& Shank,2016, p18)

1. To express your content using an engaging blend of Animations, images, audio, and text in written form, e-learning is minimalist since it does not use apps that have been demonstrated to promote learning. And at most, most learners lose focus within 15 minutes.

2. Independent of the method of delivery, every training design process must identify key skills that support operational goals and create a curriculum on the activities that constitute those skills.

3. One lesson we have learned from over 50 years of pure discovery learning research is that it is rarely working. Instead, we suggest a standardized method of e-learning that provides learners with sufficient guidance.

Welsh et al ( 2003) reported other drawbacks such as; A) expenses, b) lack of interplay between practitioners in many e-learning courses (c) increased effort and planning, (d) training needs in design, IT infrastructure, and change management.

\section{E-learning classifications:}

Negash et al. (2008) classified e-learning into six types based on the redefinitions of the terms "presence" and 
"communication. They are illustrated in the following table:

Table 1. E-Learning classifications

\begin{tabular}{|c|c|c|c|}
\hline Classification & Presence* $^{*}$ & eCommunication** $^{*}$ & Alias \\
\hline Type I & Yes & No & Face-to-Face \\
\hline Type II & No & No & Self-Learning \\
\hline Type III & No & Yes & Asynchronous \\
\hline Type IV & Yes & Yes & Synchronous \\
\hline Type V & Occasional & Yes & $\begin{array}{c}\text { Blended/Hybrid- } \\
\text { asynchronous }\end{array}$ \\
\hline Type VI & Yes & Yes & $\begin{array}{c}\text { Blended/Hybrid- } \\
\text { synchronous }\end{array}$ \\
\hline
\end{tabular}

* Presence is defined as real-time presence where both instructor and learner are present at the time of content delivery; it includes physical and virtual presence

**E-communication refers to whether the content delivery includes electronic communication or not.

Source: Negash et al. (2008)

\section{Type 1: Face-to-face learning}

The teachers meet the learners face to face in the classroom at the time of the content delivery, using traditional aids such as PowerPoint slides, and audiovisual aids. Thus, there are no e-learning tools used.

\section{Type 2: Student-centered learning.}

There is no communication here between teachers and students. The learners depend on themselves using recordings of materials.

\section{Type 3: Asynchronous}

Students access the material through pre-registered content, without any virtual or physical presence. Communication happens through e-learning technologies.

\section{Type 4: Synchronous}

It is synchronous e-learning, often called "real-time." The teacher and learner may not interact physically in synchronous e-learning, yet they still interact remotely through content delivery because e-learning technology mediates virtual training. 


\section{Type 5: Blended asynchronous}

This type is a mix of asynchronous and face-to-face elearning. Content is learned through frequent face-to-face meetings and e-communication

\section{Type 6: Blended synchronous}

It is an e-learning platform that is mixed or hybrid and still has a presence. E-communication is widely used in this environment much as in an asynchronous format. Class sessions are directed with conventional face-to-face sessions and virtual presence.

\section{E-learning theories}

Mayes \& Freitas (2004, p5) pointed out that 'learning theories provide empirically-based accounts of the variables that influence the learning process and describe how that influence takes place.' Behaviourism, Cognitivism, Constructivism, and active learning are the foundation for good practice and the creation of approaches for e-learning( Pange \& Pange,2011). Holmes and Gardner (2006) discussed these main theories in detail. Socioconstructivism encompasses our conception of how individuals learn in a social setting, which applies to the learning community that enhances their practices by mutual reflection which exchange knowledge through the definition of their members learning together.

\section{Behaviourism}

Behaviorism is undoubtedly the oldest and most commonly known of the three primary theoretical structures that underpin the theory of education and e-learning. Classical behaviorism is based on the idea of stimulus and response in humans or animals. The 'operant' conditioning predicts that specific behaviors can be 'taken' by enhancing desirable behaviors with suitable stimuli, with ample reinforcement of experience. In this way, an individual will develop a specific behavior that will emerge in the future when the correct stimulus or experience is given. This 
eventually became the most popular theory of learning predicting success in using rewards as stimulants for reinforcement and penalties as deterrents. Behavioral approaches tend to be frowned upon in learning, mainly because they deny the role of the individual in learning by focusing on automation as the main reason for responding.

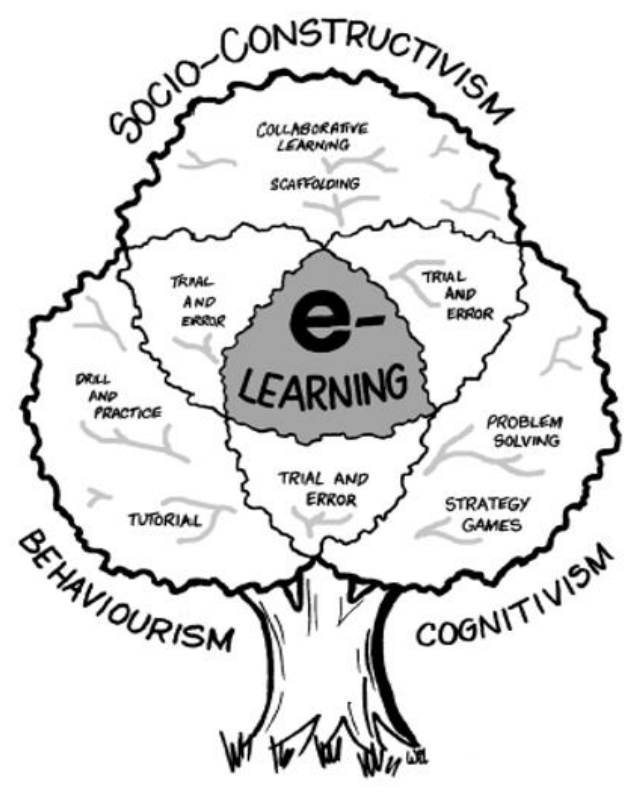

Figure 1. Overlaping theoretical underpinningsfor e-learning Source: Holmes and Gardner

\section{Cognitivism}

Cognitivism is the complete opposite of behaviorism because it emphasizes the mind and the brain's thinking processes. Piaget argued that the children undergo a maturation cycle that determines what form of learning they can achieve. Bruner, too, envisaged the development of a learner in terms of a series of steps to increase the potential to learn. Such steps must be climbed by the learner in the manner of a staircase, which means that 
certain learning skills rely on the acquisition of others before they can come into action. David Kolb argues that learning must be experiential in terms of introducing, reviewing, and implementing a new program, in creating Kurt Lewin's action cycle study plan. Vygotsky Maybe the most influential of all cognitive psychologists, mainly because his work is closely associated with the constructivist theories that dominate today's field of education. Unlike the Piagetian concept that the learner must achieve a certain phase of growth before being able to learn in that style. The theory focuses on the difference between what the learner can do now and what is beyond its control. The learner can be given problem-solving or strategic thinking tasks in e-learning contexts, which position them firmly at the core of the learning activities.

\section{Socio-constructivism}

Piaget's (1970) constructivist information theory was built on the assumption that learners do not copy or absorb ideas from the outside world but their principles must be built through active and personal research and observation. According to the cognitive constructivist theory, the learners "turn" their intelligence, knowledge, or understanding from their own intellectual and reasoning abilities into the socio-constructivist theories that are prevalent today. Those others are perhaps tutors or trainees. The model developed includes authentic learning contexts to promote learner motivation by making the learning purposeful and meaningful.

\section{Communal constructivism}

Communal constructivism refers to such an expansion in which e-learning provides the participants with the means to produce new learning for themselves and to apply and maintain their new knowledge, in whatever form it may be, in a shared body of knowledge for the benefit of existing and new students in their community(Holmes et al., 2001). 
E-learning promotes different types of interactions, with enormous opportunities for joint learning support. Developers of e-learning recently embraced a Constructivist methodology and the majority of current elearning services are based on this. They state that the learners interpret, encode, and circumambient information. And learners learn best when they can assign knowledge to a specific value. (Pange \& Pange (2011).

Reviewing closely the theories of learning discussed above, it is clear that there are parallels between the basic principles and concepts. Therefore, the design of an online learning program should follow the concepts of all the theories suggested. Behavioral concepts could be used to teach the truth, so that the "what ", the concepts of cognitivism can be used to teach practices and principles. Consequently, the « how » and the precepts of Constructivism could be used to instruct the causal relationship and the more complicated conceptions, and thus the « why » (Ally, 2004).

Table 2 shows the schematic summary of the four main

Table 2. A schematic representation of the main theoretical currents

\begin{tabular}{|c|c|c|c|}
\hline $\begin{array}{c}\text { Traditional } \\
\text { pedagogy }\end{array}$ & Behaviorist & Cognitivist & $\begin{array}{c}\text { Social } \\
\text { Constructivist }\end{array}$ \\
\hline \multicolumn{4}{|c|}{ Teaching is about ... } \\
\hline $\begin{array}{l}\text { Presenting } \\
\text { information in a } \\
\text { structured, } \\
\text { hierarchical, } \\
\text { and inductive } \\
\text { way. }\end{array}$ & $\begin{array}{l}\text { Stimulating, } \\
\text { creating and } \\
\text { reinforcing } \\
\text { appropriate } \\
\text { observable } \\
\text { behaviors. }\end{array}$ & $\begin{array}{l}\text { Presenting } \\
\text { information } \\
\text { in a } \\
\text { structured, } \\
\text { hierarchical, } \\
\text { and } \\
\text { deductive } \\
\text { way. }\end{array}$ & $\begin{array}{l}\text { Organizing learning } \\
\text { situations } \\
\text { conducive to } \\
\text { dialogue with a } \\
\text { view to provoke } \\
\text { and resolve } \\
\text { sociocognitive } \\
\text { conflicts. }\end{array}$ \\
\hline \multicolumn{4}{|c|}{ Learning is about... } \\
\hline $\begin{array}{l}\text { Following the } \\
\text { course: } \\
\text { unfolding the } \\
\text { course and the } \\
\text { tutor. }\end{array}$ & $\begin{array}{l}\text { Associating. } \\
\text { by } \\
\text { conditioning. } \\
\text { a reward to a } \\
\text { specific } \\
\text { response. }\end{array}$ & $\begin{array}{l}\text { Treating and } \\
\text { storing new } \\
\text { information } \\
\text { in an } \\
\text { organized } \\
\text { way. }\end{array}$ & $\begin{array}{l}\text { Co-constructing his } \\
\text { / her knowledge by } \\
\text { comparing his/her } \\
\text { own representations } \\
\text { with those of others. }\end{array}$ \\
\hline \multicolumn{4}{|c|}{ Appropriate teaching methods } \\
\hline $\begin{array}{l}\text { Learning by } \\
\text { course, } \\
\text { exercises and } \\
\text { assessments }\end{array}$ & $\begin{array}{l}\text { Assisted self- } \\
\text { study } \\
\text { program }\end{array}$ & $\begin{array}{l}\text { Formal } \\
\text { presentation, } \\
\text { problem- } \\
\text { solving } \\
\text { situations. }\end{array}$ & $\begin{array}{l}\text { Projects, } \\
\text { discussions, } \\
\text { exercises and work } \\
\text { based learning. }\end{array}$ \\
\hline
\end{tabular}

Source: Ouadoud et al. (2018). 
currents by linking them to the act designs of teaching and learning that correspond to them. Table 2. Shows schematic representation of the main theoretical currents.

\section{COVID-19 pandemic}

More than 90 percent of the world's students have been affected by the COVID-19 pandemic (UNESCO, 2020). Web service providers such as Google Classroom, Blackboard, Zoom, and Microsoft Teams have supported the resources that are commonly used to improve student education and learning. Such networks certainly contribute significantly to the transformation of the way education is delivered (Nagar,2020). The government of Higher education in Egypt adopted several paths to pass the crisis. The most promising and prominent one was the use of online learning through virtual platforms. The education institutions in tertiary education were advised to use virtual classes/e-learning for the continuation of the learning process for the students. Uscher-Pines et al. (2018) report that group prevention techniques, such as social distancing, may affect the spread of the virus in schools and local areas during an emerging influenza pandemic. Studies have focused on prolonged school closure. But they admitted that research is needed to develop social distance policies.

\section{Effective online education in emergencies}

For effective online education in times of emergencies, Huang et al. (2020) identified the following seven core elements:

1. Enhancing effective communications infrastructure that is capable of supporting millions of users at once providing them with online synchronous teaching through video conferencing, interactive learning tools that enable them to engage with peers across social media.

2. Utilizing friendly learning platforms is helpful for students in discovering and storing information, 
building knowledge, engaging with others, communicating understanding, and concretely assessing learning results.

3. Providing appropriate interactive resources for online learning, including online media and activities.

4. Directing learners to implement successful learning strategies individually or in groups.

5. Fostering efficient approaches to teaching by implementing varied techniques and methods of teaching.

6. Offering teachers and learners support services on learning as well as initiatives, using effective learning agendas, instruments, and references.

7. Strengthening partnerships among governments, companies, and educational institutions.

\section{Barriers of E-learning during the COVID-19 phase}

Oxford Dictionary (2015), defines a barrier as "a fence or an obstacle that prevents movement or access". Also, Schoepp (2005, p. 2) gives another definition of a barrier, which is "any condition that makes it difficult to make progress or to achieve an objective". E-learning implementation is not always smooth or efficient. It differs from one country to another, due to various factors such as culture, context, and readiness (Almaiah,2020). During the COVID-19 outbreak, e-learning was quickly adopted by schools and universities. Therefore, schools with little or no experience with e-learning tools are experiencing obstacles and problems, especially teachers as they are not trained on how to use online applications (Zaharah \& Kirilova, 2020).

Similarly, Almanthari et al (2020) reported four main barriers to e-learning implementation: Teachers, school, curricula, and students. Furthermore, there was a correlative relationship among barriers. They affect each 
other positively and the barrier that has the highest effect is the student level on others.

Table 3. Classification of barriers faced by teachers in using e-learning

\begin{tabular}{ll}
\hline Type of Barrier & Description \\
\hline School Level & Availability of software and hardware, internet, textbooks, school policy, time and technical support \\
Teacher Level & Confidence, knowledge, belief and experience \\
Curriculum Level & Structure of contents, assessment, e-learning resource that is in line with the curriculum \\
Student Level & Skill and knowledge, motivation, e-learning infrastructure \\
\hline
\end{tabular}

Source: Almanthari et al (2020)

Reviewing the literature, there are many barriers to elearning, such as hardware, access, technical support, pedagogy, belief or personal preferences (Ertmer, 1999); lack of ICT resources; knowledge and skills of teachers; (Pelgrum,2001); levels of teachers, schools and system (Balanskat, et al.,2006). Reviewing the literature, we find the obstacles of e-learning include a variety of concerns of the nature of different types. Accessibility to IT technology, and the absence of an e-learning course and techniques for evaluating student progress efficiently limit what educators can instruct. Motivation and attitudes towards online learning and teaching, and faith in the use of e-learning technologies affect how and when learners learn. These obstacles must be taken into consideration when dealing with phases such as a pandemic that requires teachers and students to adjust their teaching styles and techniques to a new style of teaching and learning (Almanthari et al., 2020). The overall student satisfaction with the applied teaching-learning process is a necessary condition for effective e-learning. (Teo, 2010). In the same vein, many other studies reported many challenges and difficulties in applying e-learning. These studies reported the failure of using e-learning in many contexts. Main reasons for failure are highlighted in table (4) 
Table ( 4 ) different reasons for the failure of e-learning

\begin{tabular}{|c|c|c|}
\hline Reasons for failures & Description & studies \\
\hline $\begin{array}{l}\text { Technological } \\
\text { Challenges }\end{array}$ & $\begin{array}{l}\text { Students } \\
\text { facing } \\
\text { using e-learning system }\end{array}$ & $\begin{array}{l}\text { Almaiah and Almulhem (2018) } \\
\text { Almaiah and Alyoussef (2019), } \\
\text { Al-Araibi et al. (2019) }\end{array}$ \\
\hline $\begin{array}{l}\text { Lack of technical } \\
\text { support }\end{array}$ & $\begin{array}{l}\text { Unavailability of technical } \\
\text { staff and lack of support of } \\
\text { facilities to do various } \\
\text { activities and Slow speed of } \\
\text { internet and connection } \\
\text { problems during e-learning } \\
\text { process. }\end{array}$ & $\begin{array}{l}\text { Eltahir (2019) Al-Azawei et al. } \\
\text { (2016). }\end{array}$ \\
\hline Lack of Awareness & $\begin{array}{l}\text { Lack of knowledge of } \\
\text { technology and computer } \\
\text { skills and students' } \\
\text { hesitation of bearing their } \\
\text { e-learning responsibility to } \\
\text { learn. }\end{array}$ & $\begin{array}{l}\text { Alajmi et al., (Ali et al. 2018), } \\
\text { Al-Araibi et al. (2019), Naveed } \\
\text { et al. (2017), Al Gamdi and } \\
\text { Samarji (2016). }\end{array}$ \\
\hline $\begin{array}{l}\text { Readiness of } \\
\text { universities to use e- } \\
\text { learning tools and } \\
\text { platforms }\end{array}$ & $\begin{array}{lr}\text { Students } & \begin{array}{l}\text { possessing } \\
\text { inconsistent } \\
\text { e-learning }\end{array} \\
\text { readiness over time }\end{array}$ & $\begin{array}{l}\text { Al-Araibi et al. (2019), Eltahir } \\
\text { (2019), Naveed et al. (2017) }\end{array}$ \\
\hline Course quality & $\begin{array}{l}\text { Content Course having less } \\
\text { quality for interactive } \\
\text { communication }\end{array}$ & $\begin{array}{l}\text { Almaiah and Almulhem (2018), } \\
\text { Almaiah and Alyoussef (2019) }\end{array}$ \\
\hline $\begin{array}{l}\text { compliance } \\
\text { content }\end{array}$ & $\begin{array}{l}\text { Lack of compliance of } \\
\text { course content to students } \\
\text { needs }\end{array}$ & $\begin{array}{l}\text { Ozudogru and Hismanoglu } \\
\text { (2016), Almaiah and Almulhem } \\
(2018) \text {, Almaiah and Alyoussef } \\
(2019) \text { Almaiah and Man (2016) }\end{array}$ \\
\hline Course content & $\begin{array}{l}\text { Course content may not be } \\
\text { accurate or relevant to } \\
\text { students' needs }\end{array}$ & $\begin{array}{l}\text { Almaiah and Almulhem (2018), } \\
\text { Almaiah and Alyoussef (2019) } \\
\text { Almaiah and Man (2016) }\end{array}$ \\
\hline $\begin{array}{l}\text { IT skills of Faculty } \\
\text { members }\end{array}$ & $\begin{array}{l}\text { Weak IT skills of faculty } \\
\text { members }\end{array}$ & $\begin{array}{l}\text { Almaiah and Alyoussef (2019), } \\
\text { Iqbal and Ahmad (2010), } \\
\text { Radijeng (2010), Nawaz and } \\
\text { Khan (2012) }\end{array}$ \\
\hline $\begin{array}{l}\text { Teachers' } \\
\text { acceptance of } \\
\text { e-learning systems }\end{array}$ & $\begin{array}{l}\text { Teachers' may not accept } \\
\text { technology use. }\end{array}$ & $\begin{array}{l}\text { Vershitskaya et al. (2020), Teo } \\
\text { (2011), Almaiah and Almulhem } \\
\text { (2018) }\end{array}$ \\
\hline
\end{tabular}

\section{Perceptions of e-learning}

The perception of students is a crucial component that evaluates their acceptance of e-learning courses; positive attitudes and potentials of aims and tasks reflect the perception of students about online courses (MartínRodríguez et al. , 2015; Aviram \& Tami, 2004). Student satisfaction is only one more measure of educational quality. There is a positive correlation between a high level of satisfaction and the likelihood of learning process 
success, which means progress in academic achievement. According to Teo (2014), E-learning research has generally focused on student engagement with a teacher or the perception of a particular LMS, and little knowledge is available about the key elements that inspire educators to engage in e-learning. Thus, it was revealed that perceptions of students and instructors are among the most important factors that guarantee the success of system application and it is affected by other factors such as, design of the course, progress, and skill in using technology, design of the system, and environment (Wang \& Bagakas, 2003).

\section{Previous Studies}

Germann et al. ( 2019) and Faherty et al. (2019) addressed the possibility of closing schools during the pandemic influenza as well as rearranging classes, restricting the community works movement of students in the classroom and creating incentives for distance learning for days off. Ash (2014) suggested that distance learning can be facilitated during the Flu Crisis by technology such as the internet, mobile, radio, television, or mobile messaging, or email. Muirhead's study (2000), admits that online learning is new to schools and can be considered to improve traditional schools and home-schooling. Various studies have shown that while there are some instances of a plan to use distance / online learning during the pandemic, they are mainly focused on small situations and not a global crisis as in COVID-19 pandemic of 2020. Results from various studies indicate that in school or higher education, virtual teaching environments can be used effectively in the event of providing sufficient technological environment and support.

Smart \& Cappel (2006 ) explored students ' expectations of incorporating online elements into two Business Undergraduate courses where students completed online 
learning modules before class discussion. The study revealed that the students in an elective course considerably rated the online modules better than those in a required course. Koohang \& Durante (2003) measured the perceptions of the learners towards a portion of the blended program's web-based distance learning activities/ assignments. Their study concluded that overall students perceived that the portion of their hybrid program's webbased distance learning activities/ assignments promoted learning. In his study, McEwen (2001) found that the learning process occurred in both classes, whether conventional instruction aided by the web or provided online. He concluded that online learning offers better access to the populations in which we live.

Volery \& Lord (2000) investigated the Australian university's online business course to determine their attitudes to and use of the online course delivery method. Keller \& Cernerud (2002) investigated students' perceptions of e-learning in Sweden. The findings of the study proved that the strategy of implementing the elearning system at the university level was more effective in affecting students' perceptions than the individual background variables. Learners did not consider access to e-learning on campus as an advantage. Nagar (2020) identified the perception of students towards e-learning amid the COVID-19 lockdown period in India.

All previously mentioned studies agreed on the effectiveness of using online learning in achieving the desired learning goals as well as the positive perceptions of students towards online learning. Batara \& Rapat (2020) applied an online learning system that is based on the Internet. The implemented framework is a software that facilitates the ongoing teaching and online learning process across the internet. The software is mounted on the server 
and can be accessed by participants in online learning programs on their PC / cell from browser applications and the development of a university that is not restricted. Teo's study (2014) explored the factors that explain satisfaction with e-learning among pre-service teachers. They analyzed the following variables: satisfaction (student), quality of tutors (teacher), perceived usefulness (course), perceived ease of use (technology), delivery of courses (system design), and ease of use (environmental) conditions. The research question was "Which factors are significant in explaining pre-service teachers' e-learning satisfaction?" The findings showed that all factors were significant predictors of e-learning satisfaction. However, the facilitating conditions construct was found to be a significant mediator of perceived ease of use and satisfaction.

\section{The problem of the study}

Technologies used in other parts of the world cannot promote student learning, because they endorse lecturebased teaching and do not strengthen student-centric pedagogy. The above-mentioned realities indicate that expectations of technology adoption by teachers and students play a crucial role in the positive incorporation of technology into language learning and instruction. In Egypt, the readiness to use ICT differs from private tertiary education to the governmental sector. Private universities use e-learning platforms as a base and integral part of their education. But, the case is different in the governmental universities. They try to use e-learning which depends on providing some PDF and PPT documents that support lectures. This is because of many obstacles such as the cost of infrastructure and availability of the internet and other barriers. The lockdown phase of COVID-19 necessitated that a solution must be found immediately to help students complete the semester and fulfill their requirements. So, all 
universities in Egypt, as it was the case all over the world, began to activate e-learning with all forms whether synchronous or asynchronous. The current study tries to discover students' and teachers' perceptions about the use of e-learning during this critical period which still at the time of preparing this study not passed yet. Challenges that face the implementation of e-learning will be dealt with through reviewing literature and surveying perceptions.

\section{Questions of the study}

The current study attempted to answer the following questions:

- What are teachers' perceptions of using e-learning during the COVID-19 Lockdown Phase?

- What are students' perceptions of using e-learning during the COVID-19 Lockdown Phase?

- Is there any difference between students' and teachers' perceptions of using e-learning during the COVID-19 Lockdown Phase?

- What are the main challenges that face the e-learning system usage during COVID-19 Pandemic?

\section{Significance of the study}

The significance of the current study arises from the importance of integrating technology in the field of education specifically during times of crisis. During the time of COVID-19 lockdown, there was an urgent need to save the situation by completing the courses and exams online to activate the idea of "Stay Home, Stay Safe". So, the only solution was online learning. the study here uncovers the challenges of relying on e-learning during this phase as well as students' and teachers' perceptions. Thus, trying to benefit from pitfalls for future promises.

\section{Method}

The current study used a qualitative and quantitative approach to treat data gathered from the participants of the study through the instruments used. The study used two 
surveys that ended with open-ended questions. They were analyzed statistically using the SPSS program.

\section{Participants}

Participants of the study were chosen from four universities in Egypt (two foreign universities and two governmental universities) which applied e-learning during and at the end of the second semester 2019-2020. Universities included BUE (British University in Egypt), RUC (Russian University in Cairo), Cairo University, and Zagazig University. The number of participants was (77) for students and (13) for staff members.

\section{Instruments}

\section{A students reflection survey (App. A)}

The survey consisted of (39) statements with responses based on a 5-point Likert scale ranging from strongly disagree to strongly agree. The survey included (36) closed questions and (3) open ended questions. It was adopted from Filimban (2008), Newsome (2008) and Mamattah, (2016) . For the sake of reliability, Alfa Cronbach's reliability was used. Reliability was (0.947) which proved to be greatly suitable.

Students reflection survey was classified into 10 categories as follows:

1. Ease of Use

2. Instructional Design

3. Learning Outcomes

4. Empowerment

5. Critical Thinking Skills

6. Online Program

7. Professionalism

8. Alignment

9. Assessments

\section{An instructors' reflection survey (App. B)}

The survey consisted of (25) statements with responses based on 5 Likert scales ranging from strongly disagree to 
strongly agree. The survey included (18) closed questions and (7) open-ended questions. The survey was adopted from Filimban (2008) with adaptation and modifications. For the sake of reliability, Alfa Cronbach's reliability was used. Reliability was $(0.783)$ which proved to be reliable. The instructors reflection survey was divided into 6 categories as follows:

1. Instructional Design and Delivery

2. Student Learning Outcomes:

3. Assessment

4. Students empowerment

5. Critical Thinking Skills

6. Alignment

\section{Data Analysis and Results:}

To answer the questions of the study, the quantitative and qualitative data were obtained from the teachers' and students' surveys. Data were analyzed using SPSS program according to the following steps:

\section{Question 1:}

What are teachers' perceptions of using e-learning during the COVID -19 Lockdown Phase? To answer the first question, data received from the instructor's reflection survey was analyzed using the SPSS program. Table (5) shows frequencies, means, standard deviations, and general attitudes of teachers' responses.

Table (5) shows the main categories of instructor's perceptions as follows:

\section{Instructional Design and Delivery}

Figure (2) shows the means of the students' responses to instructional design delivery items which imply the general agreement attitude of instructors. Mean of the item; "The course structure and materials are well organized was (3.92). whereas the mean of the item "The course is designed with various visual, textual, and/or auditory activities that improve the students' learning " was (3.76). 
The mean of the item " The course content is appropriate and up-to-date " was (3.61) This reflects the general attitude of agreement towards the instructional design delivery of the e-learning course

Table (5) Teachers' reflection survey

\begin{tabular}{|c|c|c|c|c|c|c|c|c|c|c|}
\hline & $\begin{array}{l}\text { Statem } \\
\text { ent }\end{array}$ & Freq. & $\begin{array}{l}\text { Strongly } \\
\text { disagree }\end{array}$ & Disagree & Neutral & Agree & $\begin{array}{l}\text { Strongly } \\
\text { agree }\end{array}$ & M & SD & $\begin{array}{l}\text { General } \\
\text { attitude }\end{array}$ \\
\hline \multirow{3}{*}{ 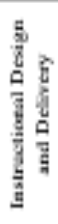 } & 1 & $\begin{array}{l}F \\
5\end{array}$ & 0 & 17.7 & 0 & $\begin{array}{l}10 \\
84.6\end{array}$ & $\begin{array}{l}1 \\
7.7\end{array}$ & 3.92 & .64 & Aggte \\
\hline & 2 & & 0 & $\begin{array}{l}2 \\
15.4\end{array}$ & 0 & $\begin{array}{l}10 \\
76.9\end{array}$ & $\begin{array}{l}1 \\
7.7\end{array}$ & 3.76 & .38 & Agrte \\
\hline & 3 & & $\begin{array}{l}1 \\
7.7\end{array}$ & $\begin{array}{l}2 \\
15.4\end{array}$ & 00 & $\begin{array}{l}8 \\
61.5\end{array}$ & $\begin{array}{l}2 \\
15.4\end{array}$ & 3.61 & 1.19 & Agrte \\
\hline \multirow{3}{*}{ 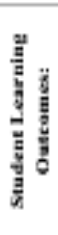 } & 4 & & 0 & $\begin{array}{l}1 \\
7.7\end{array}$ & $\begin{array}{l}1 \\
7.7\end{array}$ & $\begin{array}{l}8 \\
61.5\end{array}$ & $\begin{array}{l}3 \\
23.1\end{array}$ & 4 & .81 & Agtre \\
\hline & 5 & & 0 & 0 & 0 & $\begin{array}{l}10 \\
76.9\end{array}$ & $\begin{array}{l}3 \\
23.1\end{array}$ & 4.23 & .43 & $\begin{array}{l}\text { Strundy/y } \\
\text { agrte }\end{array}$ \\
\hline & 6 & & 0 & 0 & 0 & $\begin{array}{l}11 \\
84.6\end{array}$ & $\begin{array}{l}2 \\
15,4\end{array}$ & 4.15 & .37 & Agtre \\
\hline \multirow{3}{*}{$\begin{array}{l}\frac{1}{3} \\
\frac{1}{3} \\
\frac{1}{3}\end{array}$} & 7 & & 0 & 0 & 0 & $\begin{array}{l}11 \\
84.6\end{array}$ & $\begin{array}{l}2 \\
15.4\end{array}$ & 4.15 & .37 & Agfte \\
\hline & 8 & & 0 & 0 & $\begin{array}{l}5 \\
38.5\end{array}$ & $\begin{array}{l}8 \\
61.5\end{array}$ & 0 & 3.6! & .50 & Aggte \\
\hline & 9 & & 0 & 0 & 0 & $\begin{array}{l}10 \\
76.9\end{array}$ & $\begin{array}{l}3 \\
23.1\end{array}$ & 4.15 & .43 & Agtre \\
\hline \multirow{3}{*}{ 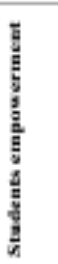 } & 10 & & 0 & 0 & $\begin{array}{l}1 \\
p .7\end{array}$ & $\begin{array}{l}6 \\
46.2\end{array}$ & $\begin{array}{l}6 \\
46.2\end{array}$ & 4.38 & .65 & $\begin{array}{l}\text { Strungly } \\
\text { aute }\end{array}$ \\
\hline & 11 & & 0 & $\begin{array}{l}2 \\
15.4\end{array}$ & $\begin{array}{l}2 \\
15.4\end{array}$ & $\begin{array}{l}4 \\
30.8\end{array}$ & $\begin{array}{l}5 \\
38.5\end{array}$ & 4.38 & 1.11 & $\begin{array}{l}\text { Struingly } \\
\text { augte }\end{array}$ \\
\hline & 12 & & 0 & 0 & $\begin{array}{l}2 \\
15.4\end{array}$ & $\begin{array}{l}6 \\
46.4\end{array}$ & $\begin{array}{l}5 \\
38.5\end{array}$ & 4.23 & .72 & $\begin{array}{l}\text { Strungly } \\
\text { ayte }\end{array}$ \\
\hline \multirow{3}{*}{ 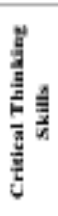 } & 13 & & 0 & 0 & 0 & 0 & $\begin{array}{l}13 \\
100\end{array}$ & 3.92 & .75 & Agrte \\
\hline & 14 & & 0 & 0 & 0 & 0 & $\begin{array}{l}13 \\
100\end{array}$ & 4.15 & .80 & Agrte \\
\hline & 15 & & 0 & 0 & 00 & 0 & $\begin{array}{l}13 \\
100\end{array}$ & 4 & .81 & Aggte \\
\hline \multirow{3}{*}{$\frac{y}{2}$} & 16 & & 0 & 0 & $\begin{array}{l}2 \\
15.4\end{array}$ & $\begin{array}{l}8 \\
61.5\end{array}$ & $\begin{array}{l}3 \\
23.1\end{array}$ & 4 & .64 & Agrte \\
\hline & 17 & & 0 & 0 & 0 & $\begin{array}{l}11 \\
84.6\end{array}$ & $\begin{array}{l}2 \\
15.4\end{array}$ & 4.15 & .37 & Aggte \\
\hline & 18 & & 0 & 0 & 0 & $\begin{array}{l}8 \\
61.5\end{array}$ & $\begin{array}{l}5 \\
38.5\end{array}$ & 4.38 & .50 & $\begin{array}{l}\text { Stringly } \\
\text { augte }\end{array}$ \\
\hline
\end{tabular}


Instructional design and delivery

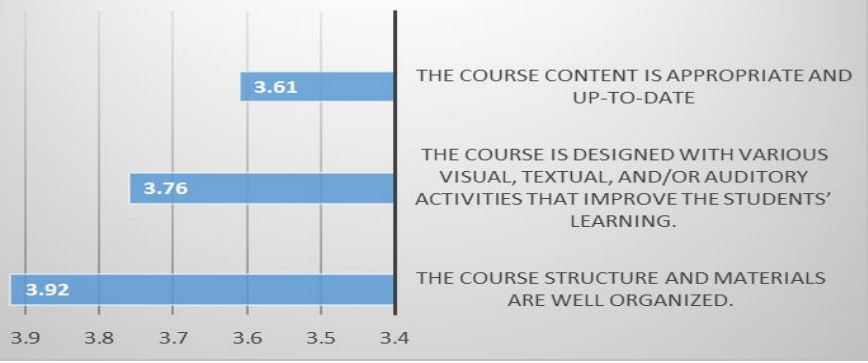

Figure (2). Instructional design and delivery

\section{Student Learning Outcomes}

Figure (3) shows the means of learning outcome items. Mean of the item "Sufficient time is allowed for achieving outcomes" was (4.15), mean of the item " The tasks that are required to complete the class are clearly defined" was (4.23) and the mean of the item "The learning outcomes outlined in the syllabus are clearly explained" was (4). Al means show the general attitude of instructors' agreement towards learning outcomes.

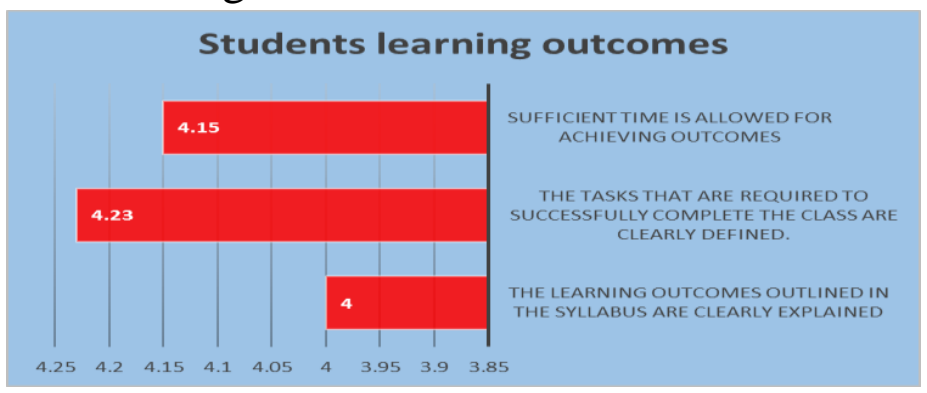

\section{Assessment}

Figure (3). Students learning outcomes

Figure (4) shows means of assessment items as follows: the mean of the responses to the item "Feedback on assignments is provided within a reasonable time frame." was (4.15), whereas the mean of the responses to the item "Assignments with appropriate levels of difficulty are provided." was (3.61). the mean of the responses to the item "How students will be graded in 
the class is clearly explained." was (4.15). thus the general attitude of instructors towards assessment was agreement.

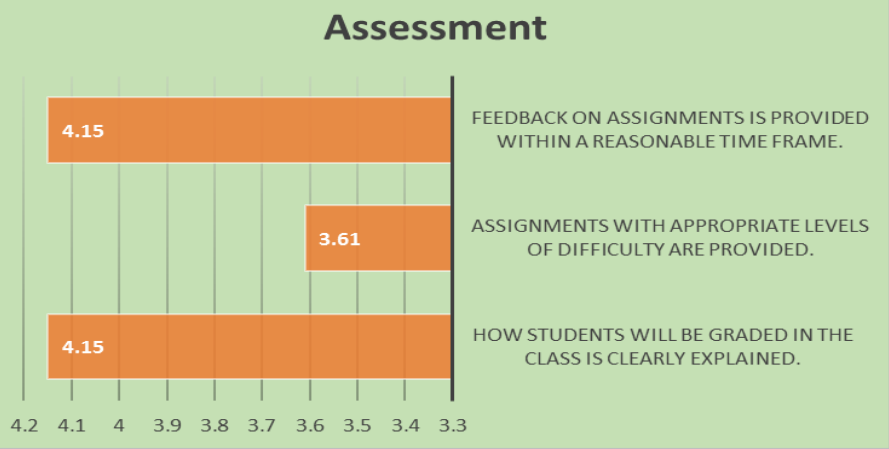

\section{Students' empowerment}

Figure (4). Assessment

Figure (5) shows the means of assessment as follows: the mean of the responses to the item " The students are given a voice in how they will be graded." was (4.38) whereas the mean of the responses to the item " The students are given opportunities to share their cultural backgrounds." was (4.38) . The mean of the responses to the item " "The students are given opportunities to express themselves. was (4.23) which all denote the general attitude of strong agreement.

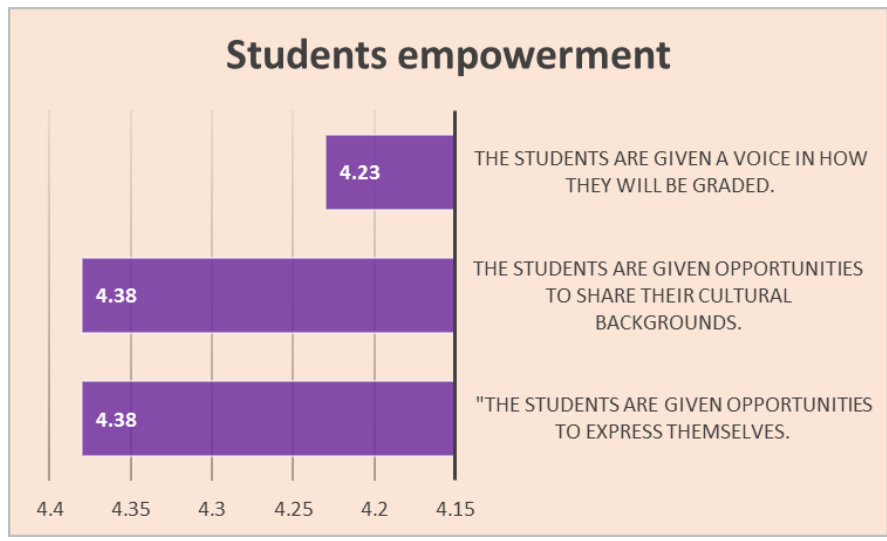

Figure (5). Students empowerment 


\section{Critical Thinking Skills}

Figure (6) shows the means of critical thinking item responses. The mean of the responses to the item " Students are required to problem-solve" was (4). the mean of the responses to the item "Students are required to analyze, synthesize, and interpret the information" was (4.15). The mean of the responses to the item "Students are required to think in-depth about a subject. " was (3.92). Thus, the general attitude was "agreement".

\section{Critical thinking skills}

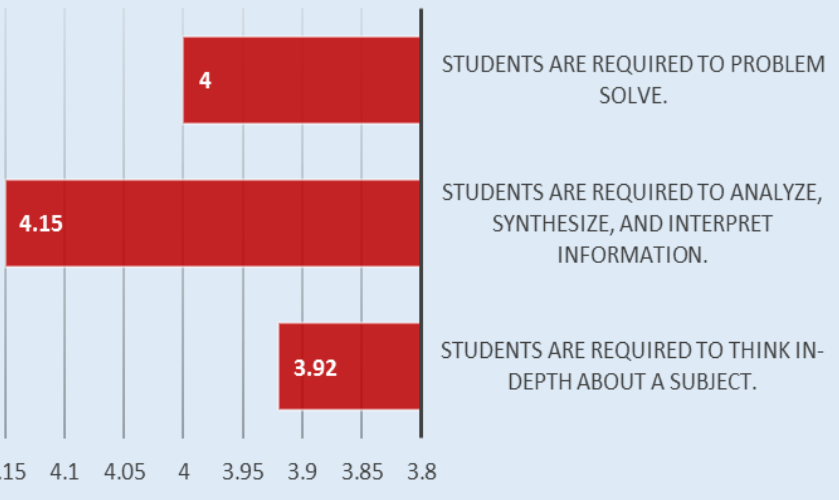

Figure (6). Critical thinking skills

\section{Alignment}

Figure (7) shows the means of alignment item responses. The mean of the responses to the item" Course assessments are in 4ment with the course content and learning objectives" was (4.38). The mean of the responses to the item" Learning outcomes are in alignment with the course requirements" was (4.15). The mean of the responses to the item "Assignments that reflect student interests and abilities are provided. " was (4). Thus, the general attitude is agreement. 


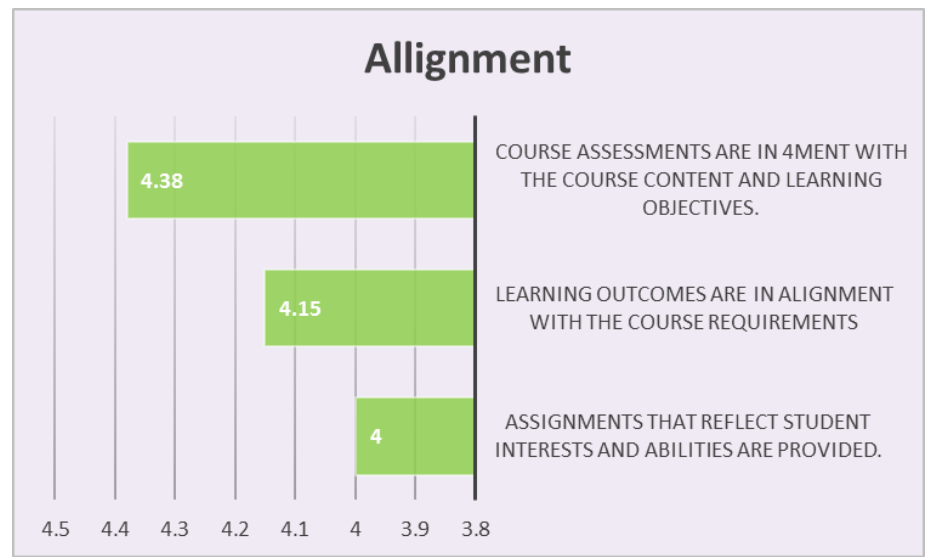

Figure (7). Alignment

\section{Open-ended questions}

The teacher reflection survey included (7) open-ended questions that received different responses. In response to the question; 'What do you think are the greatest benefits of online courses?' collaboration received (34\%), whereas accessibility received ( $21 \%$ ) and flexibility and studentcentered received $(21 \%, 13 \%)$ respectively. In answering the question; 'What do you think are the greatest drawbacks of online courses?', 57\% of responses were directed to 'lack of face to face'. Whereas $19 \%$ of the total responses were directed to 'lack of technological skills', and isolation and 'time-intensive' received $14 \%$ and $0.09 \%$ of total responses. When asked about whether the web affected their teaching methods or styles, $76 \%$ of instructors agreed that, through online teaching, they could attach a video, manage students easily and give them more assignments that enrich their critical thinking. They added that online teaching adds to their competence as teachers and they could cope with the technology and attract students' attention through varying their teaching strategies. $24 \%$ of the total number disagreed saying that nothing is affected, however, face to face interaction was missed which affects the students' participation in the class. 
The third question was; 'What assessment tools would you suggest using to evaluate the effectiveness of an online course?'. The answer included various tools such as Quiz Pedia, BB tools, presentations, electronic quizzes and tests, questionnaires, observations, interviews and exams, qualitative assessment, oral exams, tests, open discussion, student feedback, objective questions, and fill in the blanks. The question about the critical component of effective online courses included many answers such as;

-students' engagement in the online learning-teaching process.

-its usefulness as well as interest for the learners .

-assessment, motivation, and participation .

-Flexibility methods to make it more interesting.

-High-speed internet, effective platform, trained teachers or professional and skillful instructors

-Well-organized material, availability of tools .

-lack in interaction with students

-Presentations, and

-Lecturing

Question 2: What are students' perceptions of the use of e-learning during the COVID-19 Lockdown Phase? Table ( 6 ) shows frequencies, means, standard deviations, and general attitudes of students' responses.

Table ( 6) Students reflection survey

\begin{tabular}{|c|c|c|c|c|c|c|c|c|c|c|}
\hline $\begin{array}{l}\text { state } \\
\text { ment }\end{array}$ & $\begin{array}{l}\text { State } \\
\text { ment }\end{array}$ & & $\begin{array}{l}\text { Strongly } \\
\text { disagree }\end{array}$ & Disagree & $\begin{array}{l}\text { Neutr } \\
\text { al }\end{array}$ & Agree & $\begin{array}{l}\text { Strongl } \\
\text { y agree }\end{array}$ & M & SD & $\begin{array}{l}\text { General } \\
\text { attitude }\end{array}$ \\
\hline \multirow{7}{*}{ 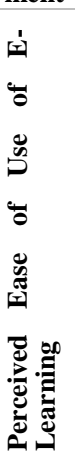 } & 1 & $\begin{array}{l}\text { Freq } \\
\%\end{array}$ & $\begin{array}{l}6 \\
7.8\end{array}$ & $\begin{array}{l}4 \\
5.2\end{array}$ & $\begin{array}{l}21 \\
27.3\end{array}$ & $\begin{array}{l}41 \\
53.2\end{array}$ & $\begin{array}{l}5 \\
6.5\end{array}$ & 3.45 & .98 & agree \\
\hline & 2 & & $\begin{array}{l}4 \\
5.2\end{array}$ & $\begin{array}{l}4 \\
5.2\end{array}$ & $\begin{array}{l}18 \\
23.4\end{array}$ & $\begin{array}{l}39 \\
50.6\end{array}$ & $\begin{array}{l}12 \\
15.6\end{array}$ & 3.66 & .98 & agree \\
\hline & 3 & Freq & $\begin{array}{l}4 \\
5.2\end{array}$ & $\begin{array}{l}9 \\
11.7\end{array}$ & $\begin{array}{l}15 \\
19.5\end{array}$ & $\begin{array}{l}34 \\
44.2\end{array}$ & $\begin{array}{l}15 \\
19.5\end{array}$ & 3.61 & 1.09 & agree \\
\hline & 4 & Freq & $\begin{array}{l}4 \\
5.2\end{array}$ & $\begin{array}{l}2 \\
2.6\end{array}$ & $\begin{array}{l}23 \\
29.9\end{array}$ & $\begin{array}{l}36 \\
46.8\end{array}$ & $\begin{array}{l}12 \\
15.6\end{array}$ & 3.64 & .95 & agree \\
\hline & 5 & Freq & $\begin{array}{l}4 \\
5.2\end{array}$ & $\begin{array}{l}9 \\
11.7\end{array}$ & $\begin{array}{l}21 \\
27.3\end{array}$ & $\begin{array}{l}36.0 \\
46.8\end{array}$ & $\begin{array}{l}7 \\
9.1\end{array}$ & 3.42 & .99 & agree \\
\hline & 6 & Freq & $\begin{array}{l}10 \\
13\end{array}$ & 24 & $\begin{array}{l}17 \\
22.1\end{array}$ & $\begin{array}{l}19 \\
24.7\end{array}$ & $\begin{array}{l}7 \\
9.1\end{array}$ & 2.85 & 1.19 & Neutral \\
\hline & 7 & Freq & $\begin{array}{l}3 \\
3.9\end{array}$ & $\begin{array}{l}13 \\
16.9\end{array}$ & $\begin{array}{l}9 \\
11.7\end{array}$ & $\begin{array}{l}37 \\
48.1\end{array}$ & $\begin{array}{l}15 \\
19.5\end{array}$ & 3.62 & 1.1 & agree \\
\hline
\end{tabular}




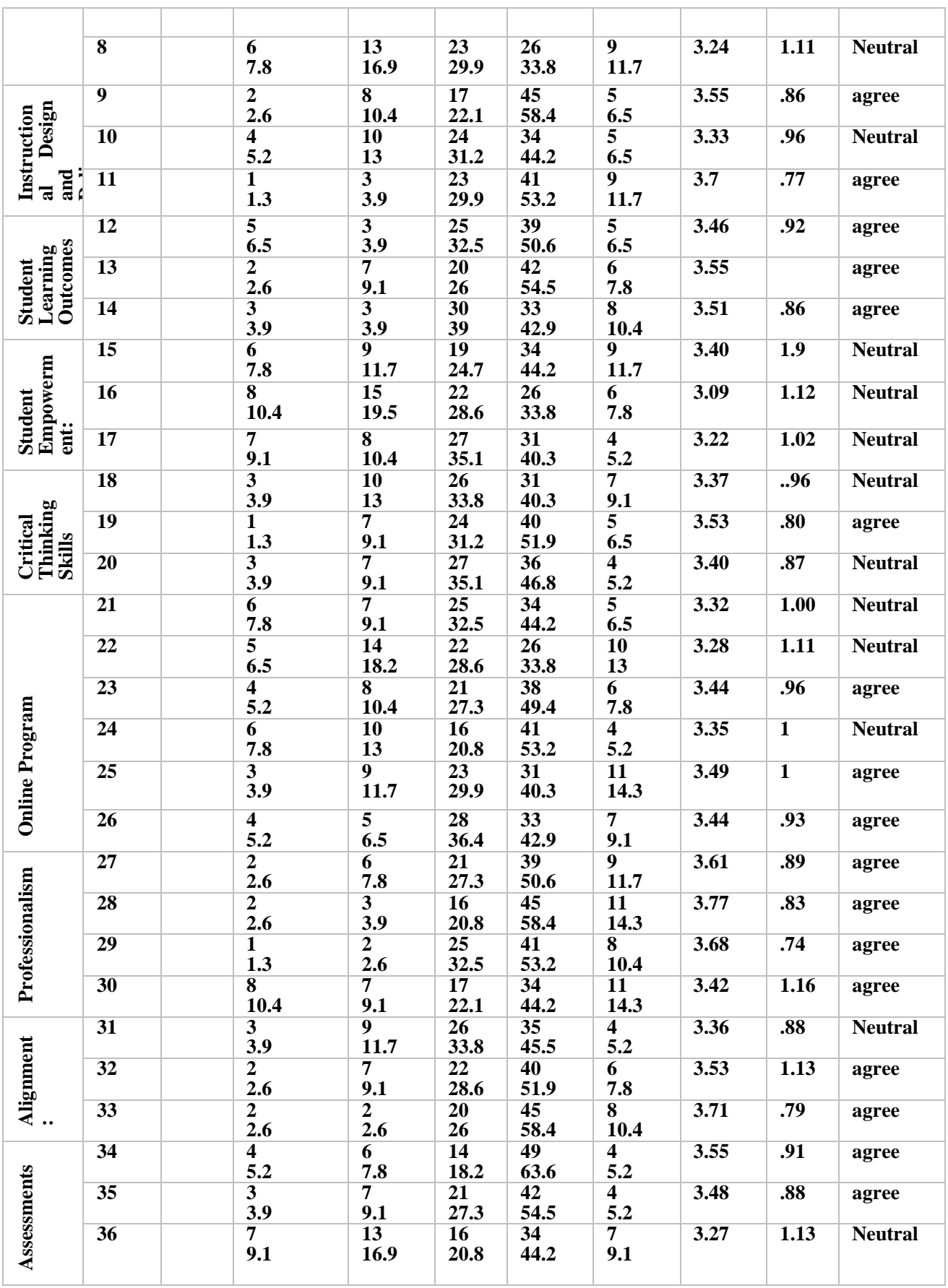


Table (6) shows the main categories of students' perceptions. They are represented as follows"

\section{Perceived ease of use:}

Figure (8) shows the means of students' responses to perceived ease of use items. Mean of being "comfortable with the fully face-to-face than online learning" responses was (3.24) which expresses neutral level as well as the item;" I prefer fully-online learning to face-to-face " with mean of (2.85). Responses to other items gave general agreement with means of (3.62), (3.42), (3.64), (3.61), (3.66), and (3.45) respectively. So, the general perceptions of students in terms of the ease of use of the e-learning tend to be satisfying.

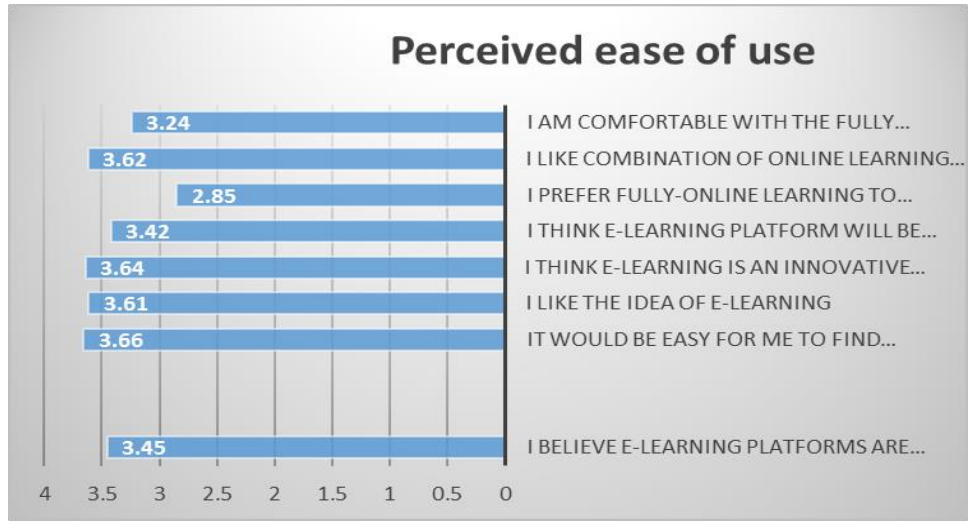

Figure (8) Perceived ease of use

\section{Instructional Design and Delivery}

Figure (9) shows the mean of students' responses to the items of the category, instructional design, and delivery. Students' mean perceptions towards appropriates of course content are (3.7), while the mean responses to the item; "The course is designed with various visual, textual, and/or auditory activities that improve my learning" was (3.33) which is a neutral attitude. The mean of students' responses to the organization of the course and material was (3.55) with a general attitude of agreement. 


\section{Instructional design and delivery}

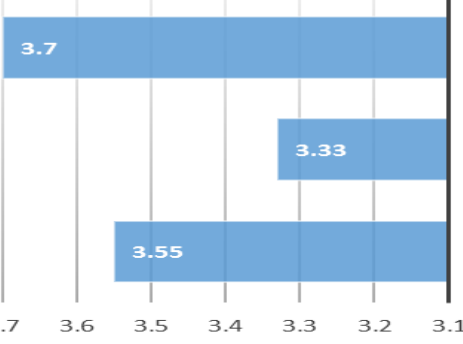

THE COURSE CONTENT IS APPROPRIATE

AND UP-TO-DATE

THE COURSE IS DESIGNED WITH VARIOUS

VISUAL, TEXTUAL, AND/OR AUDITORY

ACTIVITIES THAT IMPROVE MY LEARNING.

THE COURSE STRUCTURE AND MATERIALS ARE WELL ORGANIZED.

figure (9) Instructional Design and Delivery

\section{Student Learning Outcomes}

The general perceptions of students towards the category; "students learning outcomes tend to be agreement. Mean responses to the items; "My instructor clearly explains the learning outcomes outlined in the syllabus ", "My instructor clearly defines the tasks that are required to complete in the class." and "My instructor allows sufficient time for achieving outcomes" are; (3.46), (3.55) and (3.51) respectively.

\section{Students learning outcomes}

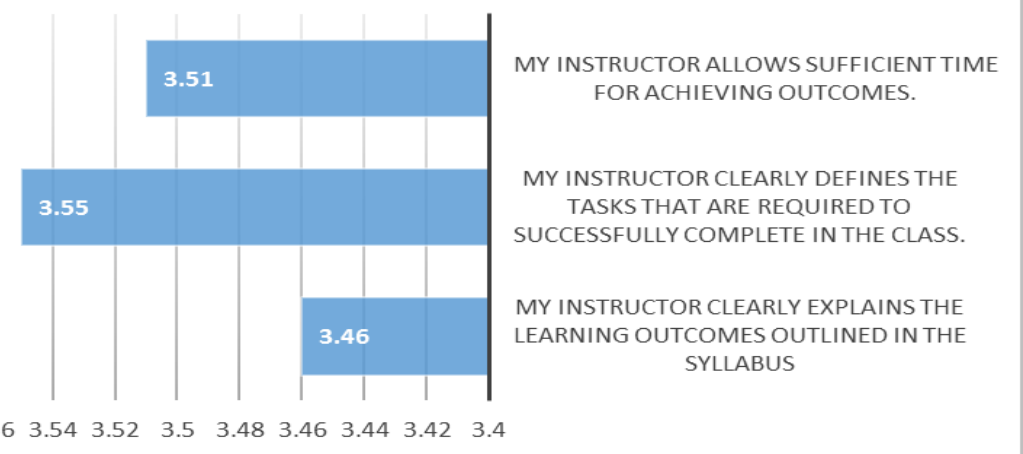

Figure (10 ) Students Learning Outcomes

\section{Students' empowerment}

According to the mean responses of students towards the category "students empowerment", the general attitude is neutral. Students could not assure that they share in the 
process of self - evaluation. So, mean responses to the items: "I feel free to express myself, my instructor allows me to have a voice in how I will be graded" and "I have opportunities to evaluate my assessment or grades" are (3.4). (3.09) and (3.22) respectively.

Student empowerment

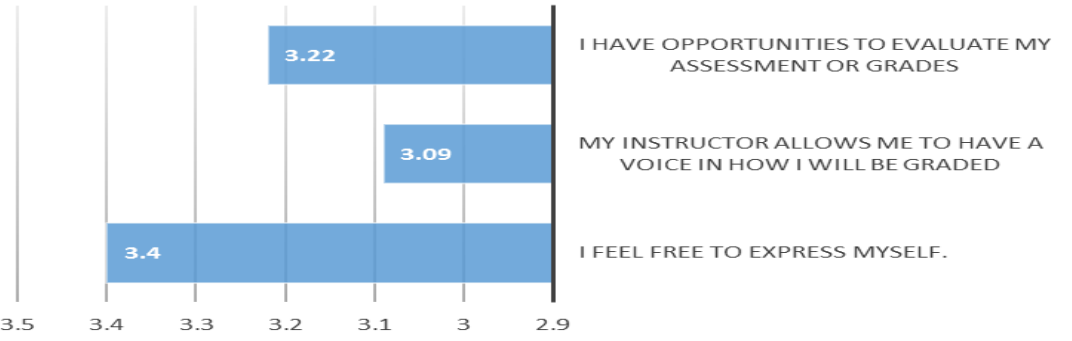

Figure ( 11 ) Students empowerment

\section{Critical Thinking Skills}

Mean responses for students to the critical thinking skills items were as follows:

The item 'My instructor requires me to think in-depth about a subject ' (3.37) which expressed a neutral attitude. Whereas the item ' My instructor requires me to analyze, synthesize, and interpret information' expressed general perception of agreement among students with mean of (3.53). the item 'instructor requires me to problem solve' expressed general attitude of neutral with mean of (3.4).

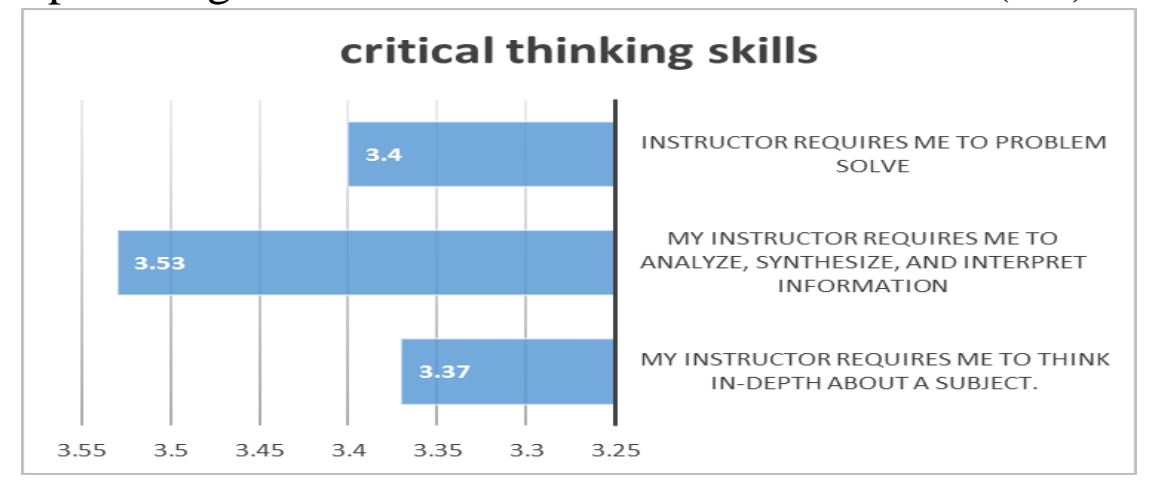

Figure (12 ) Critical Thinking Skills Online Program 
Figure (13) shows the means of students' responses to online programs ranged between 'agree' and 'neutral'. The items:' The appearance of the online program is attractive and easy to read' (3.44). I feel like I am mastering the material. (3.49). 'Any problems I reported with the web program were resolved on time'. was (3.44).This expressed the general attitude of agreement, whereas the items; 'The online program runs smoothly (3.32). 'I find the online program more convenient than meeting as a class monthly.' (3.28) 'I commonly worked with other students when completing assignments' (3.35) expressed the general neutral attitude.

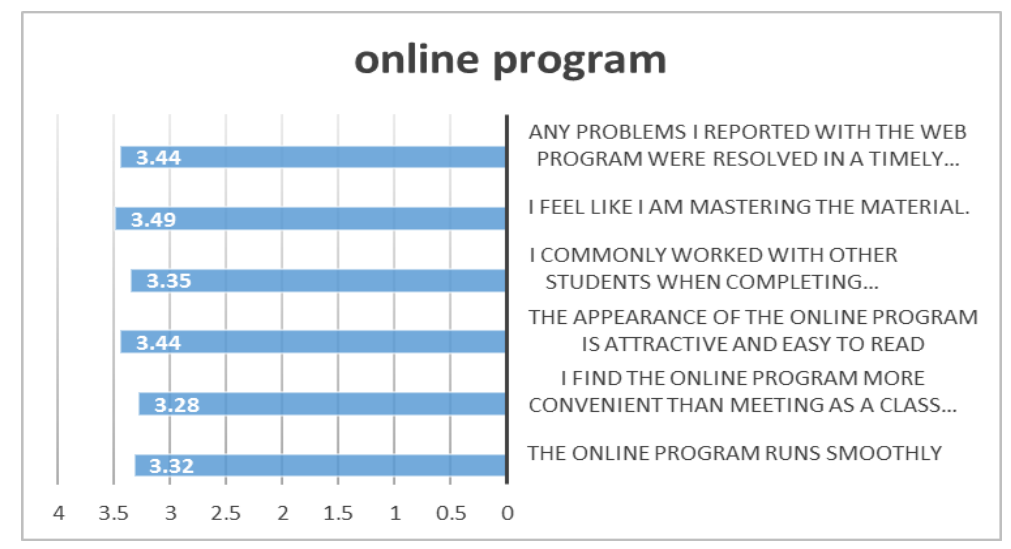

\section{Professionalism}

\section{Figure ( 13 ) Online Program}

Means of students' perceptions towards teachers' professionalism expressed general agreement. This is clear in the following items: The instructor is on time for all appointments' got (3.61). 'The instructor is helpful and courteous' got (3.77). The instructor is knowledgeable and demonstrates mastery of the subject got (3.68). I found face-to-face meetings helpful and would like to include them in further courses got (3.42). 


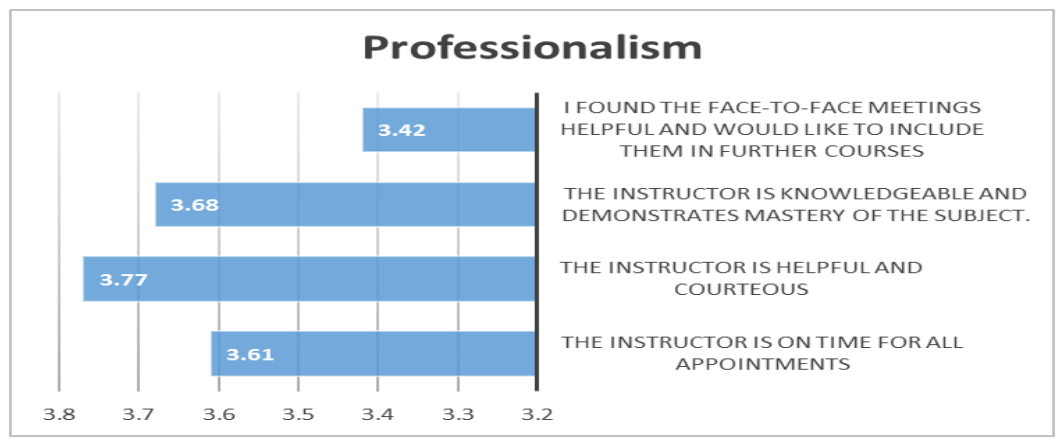

\section{Alignment:}

\section{Figure ( 14) Professionalism}

Students' perceptions towards alignment of assessment to outcomes and content agreed on the following two items: 'The learning outcomes are in agreement with the course requirements' and 'Course assessments are in agreement with the course content and learning objectives', with means of (4.15) and (4.38) respectively. Whereas they expressed general neutral perception towards the item; My instructor provides assignments that reflect my interests and abilities' with mean of (3.36).

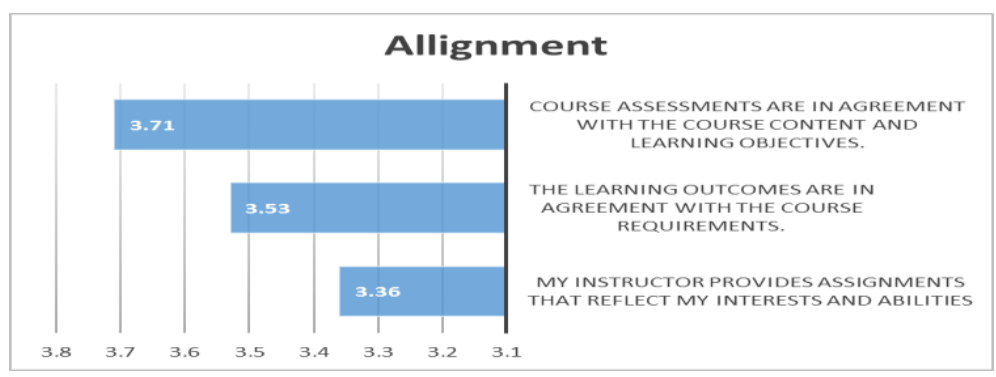

\section{Assessments}

\section{Figure (15 ) Alignment}

Figure (16) shows neutral perception for the item ' My instructor provides feedback on assignments within a reasonable time frame ' with a mean of (3.27). Whereas, the general perception of the agreement is shown with the other two items as follows; 'My instructor explains 
how students will be graded in class.' ,' My instructor provides assignments with appropriate levels of difficulty' with mean of (3.55) and (3.48) respectively .

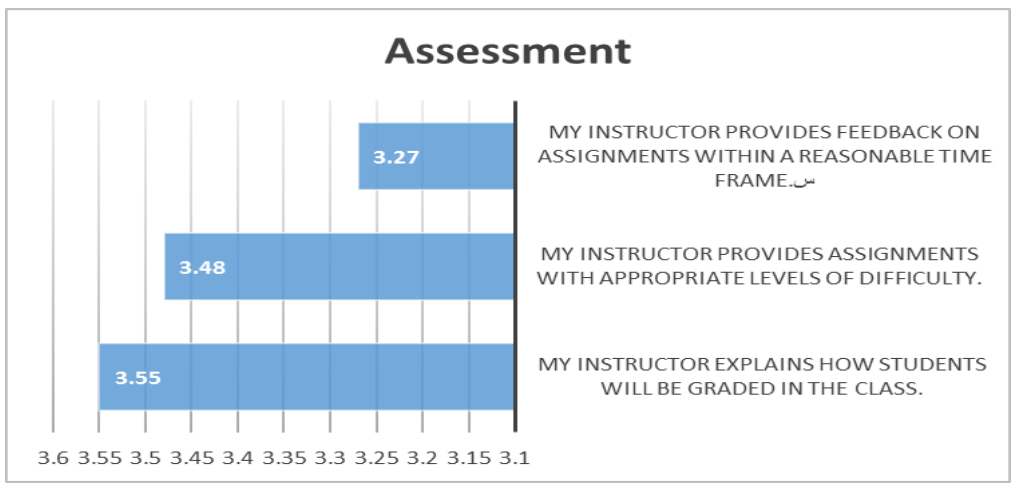

Figure (16). Assessment

\section{Open-ended questions}

In answering the question ' Aside from the technological aspects, has the web affected your learning style?', most of the students ' responses (70.2\%) agreed, and ( 29.8\%) of them denied that their learning styles were affected by the use of the web. In answering the question about the greatest drawbacks of online courses, 'lack of face-to-face interaction' received ( $33.62 \%$ ) of responses, while, 'timeintensive' received (25\%) of responses. the problem of 'Lack of technological skills for students' received (26.72 $\%$ ) of responses. Finally, the isolation problem was received $(14.65 \%)$ of the students' responses.

Question 3: Is there any difference between students' and teachers' perceptions of the use of e-learning during the COVID-19 Lockdown Phase?

To compare students' and teachers' perceptions towards the use of e-learning during the COVID-19 Lockdown Phase, the Mann-Whitney test was used, and table (7) shows the rank means and the significance. 
Table (7) Mann-Whitney test results in comparing rank mean between teachers and students' perceptions towards using elearning

\begin{tabular}{|c|c|c|c|c|c|c|c|}
\hline & group & $\mathbf{N}$ & $\begin{array}{l}\text { Mean } \\
\text { rank }\end{array}$ & $\begin{array}{l}\text { Sum of } \\
\text { ranks }\end{array}$ & $\mathbf{U}$ & $\mathbf{Z}$ & Sig. \\
\hline \multirow{2}{*}{$\begin{array}{l}\text { Instructional } \\
\text { Design differences }\end{array}$} & teachers & 13 & 56.19 & 370.50 & \multirow[t]{2}{*}{361.5} & \multirow[t]{2}{*}{1.628} & \multirow[t]{2}{*}{0.104} \\
\hline & Students & 77 & 43.69 & 3364.5 & & & \\
\hline \multirow[t]{2}{*}{ learning outcomes } & teachers & 13 & 64.23 & 835 & \multirow[t]{2}{*}{257} & \multirow[t]{2}{*}{2.887} & \multirow[t]{2}{*}{0.004} \\
\hline & Students & 77 & 42.34 & 3260 & & & \\
\hline \multirow[b]{2}{*}{ Assessment } & teachers & 13 & 64.32 & 835 & \multirow[t]{2}{*}{257} & \multirow[t]{2}{*}{2.889} & \multirow[t]{2}{*}{0.004} \\
\hline & Students & 77 & 42.34 & 3260 & & & \\
\hline \multirow[b]{2}{*}{ Alignment } & teachers & 13 & 69.62 & 905 & \multirow[t]{2}{*}{187} & \multirow[t]{2}{*}{3.670} & \multirow[t]{2}{*}{0.000} \\
\hline & Students & 77 & 41.43 & 3190 & & & \\
\hline \multirow[t]{2}{*}{ Critical thinking } & teachers & 13 & 63.69 & $828 s$ & \multirow[t]{2}{*}{264} & \multirow[t]{2}{*}{2.759} & \multirow[t]{2}{*}{0.006} \\
\hline & Students & 77 & 42.43 & 3267 & & & \\
\hline
\end{tabular}

Table (7) shows that Mann-Whitney test results comparing the rank mean between the teachers' and students' perceptions towards using e-learning. Concerning 'instructional design differences', they mean rank for teachers is (56.19) while the mean rank for students is (43.69). This means there is no significant difference between teachers ' and students' responses. In terms of 'learning outcomes', teachers' mean rank is (64.23) whereas students' mean rank is (42.34). this means that there is a significant difference between teachers' and students' responses at the level of (0.004) on behalf of teachers' responses. Comparing teachers' and students' perceptions towards 'assessment', The mean rank for teachers' perceptions is (64.32), whereas the mean rank for students' perceptions is (42.34). This means that there is a significant difference between the perceptions of the two groups on behalf of teachers' perceptions. The same applies the mean rank of teachers and students' responses in terms of alignment which are (69.62)for teachers and (41.43) for students respectively . while the mean rank for teachers in terms of critical thinking is (63.69) and for students 
(42.43). This means that there are significant differences in the two areas in favor of teachers' responses.s. These results are shown in figure (17).

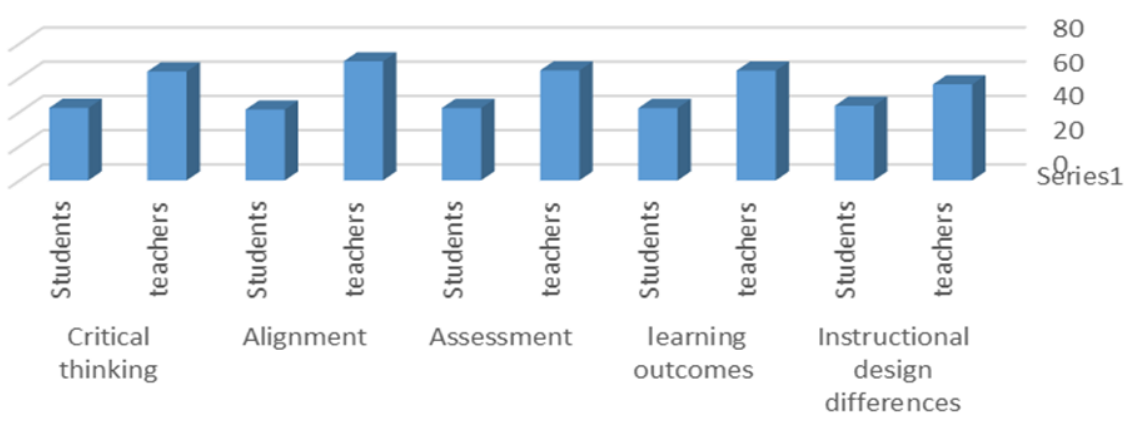

Figure (17). Rank means between teachers and students' perceptions towards using e-learning

\section{Question 4}

To answer the question; 'What are the main challenges that face the e-learning system usage during COVID-19 Pandemic? ', literature was reviewed and students' and teachers' responses were analyzed. Challenges and pitfalls differ according to the educational institution's capabilities and readiness. According to Almaiah and Almulhem (2018); Almaiah and Alyoussef (2019), and Al-Araibi et al. (2019) . The main challenges are represented in students' inability to use technology, which in turn affects the implementation of e-learning using digital platforms and applications. Sometimes this difficulty in using technology faces teachers themselves. That is due to the traditional method of teaching they used to. Lack of technical support and availability of high-speed internet are other challenges that face the implementation of e-learning in educational institutions (Eltahir, 2019) Al-Azawei et al. (2016).

Both teachers and students need continuous support to overcome any problems that may arise, specifically during 
synchronous sessions and electronic exams. Al-Araibi et al. (2019), Eltahir (2019), and Naveed et al. (2017) reported that the readiness of universities concerning providing platforms and e-courses to be used for activities, assignments, and tests forms a very important factor that helps to make e-learning runs smoothly. But that is not the case all the time. Many of the universities do not have the budget to provide such services for students. Course quality and content represent a serious obstacle in front of implementing e-learning in education. The courses used with e-learning should be equipped with interactive activities and exercises that engage students and develop their skills. The structure of the course and materials should be well organized and designed with various visual, textual, and/or auditory activities that improve the students' learning. The course content must be up -to- date. Lack of relevance, the inaccuracy of course content, and misalignment, of course, content with learners' needs and learning outcomes (Almaiah and Alyoussef, 2019). Lack of customization/adaptability of course content (Ozudogru and Hismanoglu, 2016) makes it useless to use e-learning with students. Many other challenges face the implementation of e-learning such as the feeling of isolation and the lack of face-to-face interaction and the difficulty of applying for group work.

\section{Discussion of results}

The purpose of the current study is to examine teachers' and students' perceptions of using e-learning. In the past times, it was optional to use e-learning as its use proved to be effective and innovative in developing students' technical and academic skills. On the other hand, as a result of the current pandemic of COVID-19 and the necessity of completing the second semester's courses and exams, it became an obligation to find a practical solution that saves the situation and helps pass the critical situation while 
staying at home. The study focused on students' and teachers' perceptions of e-learning implementation during the pandemic of COVID-19. It is expected that there is a general agreement between teachers' and students' perceptions. At the same time, the level of agreement may differ according to each group's experience and expectations.

The other two aims were to compare teachers' and students' perceptions and to find challenges and problems that face the implementation of e-learning in tertiary education. Students did not express full agreement to the preference of online learning or even face to face learning. This attitude may be a result of some challenges that face them during the process of e-learning such as technical problems or their lack of IT skills. At the same time, they did not refuse the idea of e-learning as it has more advantages than disadvantages. Perceived ease of use may depend on the methods offered for using the platform and its tools. According to Mohammadi, (2015). Ease of use depends on providing tools of e-mail as well as social networking, availability of recording the session, opportunities for personalized assessment, and providing the greatest interaction options. Supporting users with 'help' options improves user authority to manage their private accounts more effectively. Instructor characteristics and teaching materials as well as the design of learning contents are positively related to perceived usefulness ( Lee et al. , 2009; Liaw, 2008).

Instructional design and delivery of course content is a very important factor that affects the success of e-learning. It should be remembered that most theories of learning influenced the new industry of instructional design. Literature survey reveals that this discipline has developed out of the social sciences; the learning theories (cognitive, 
behavioral, and constructivism) are the frameworks for the discipline of instructional design (Afifi \& Alamri, 2014). Students expressed general agreement of appropriateness of course content, structure, and organization its update and suitability for e-learning implementation. It is advised to provide reliable, detailed, up-to-date, and necessary information that is important to the needs of students and is methodologically structured (Mohammadi, 2015). But they did not show any perception for the course including interactive tools. This may be because the use of online sessions was sudden as a result of the COVID -19 pandemic lockdown phase. The use of e-learning during face to face lectures depended on having assignments and quizzes through the Blackboard platform. But, having interactive activities with audio-visual tools that attract students' attention is one of the most important techniques of e-learning.

Teachers must define and declare the learning outcomes for students whether it is face-to-face or online learning. So, sufficient time should be allowed to achieve the learning outcomes using varied teaching aids. Each task given to students must be accompanied by its aim or aims. Learning outcomes must be not only declared to students ( Liaw, 2008), but also, explained to them clearly. So, the success of the e-learning process will not be achieved without understanding how to achieve the learning outcomes.

In the process of e-learning, students need to address their critical thinking skills. It is a technique that helps students to be more flexible and critical in searching for required information and critical searching of facts (Mohammadi, (2015). teachers agreed that e-learning help students solve problems, analyze, synthesize, and interpret information through deep thinking in the subject matter.

Students showed general agreement concerning the professionalism of instructors. In the e-learning process, 
teachers must be trained on the use of e-learning and on managing sessions successfully. Additionally, they should be on time and competent in the target course as well as in technical matters that may affect the fluency of the session. When comparing students' perceptions with teachers' perceptions, we find that some differences refer to students' high level of expectations that do not match reality or the authentic situation. Thus, good management, alignment between objectives and outcomes, mastery of the use of platform tools, training opportunities for both teachers and students, and the use of communication strategies guarantee the success of e-learning implementation.

\section{Conclusion}

The current study examined both teachers' and students' perceptions of e-learning during the time of COVID -19 in tertiary education. They agreed on most of the survey items which examined many areas that promote success to the e-learning process. The areas included ease of use, delivery of content, learning objectives and outcomes, critical thinking, student empowerment, assessment, and alignment. They never showed disagreement, but sometimes they showed a neutral attitude towards a few of the items. Most perceptions were positive despite some challenges that can be considered in the future.

\section{Suggestions}

- It is suggested that e-learning programs be organized to develop English language skills such as reading, vocabulary, and speaking.

- Learning strategies such as gamification can be used through e-learning to develop vocabulary knowledge and retention.

- E-learning can be used with corpus linguistics to develop students' vocabulary and reading comprehension skills. 
References

Afifi, M. K., \& Alamri, S. S. (2014). Effective Principles in Designing E-Course in Light of Learning Theories. Turkish Online Journal of Distance Education, 15(1), 128-142.

Al Gamdi, M. A., \& Samarji, A. (2016). Perceived barriers towards e-learning by faculty members at a recently established university in Saudi Arabia. International Journal of Information and Education Technology, 6(1), 23.

Al-Arabi, A. A. M., Naz'ri Bin Mahrin, M., \& Yusoff, R. C. M. (2019). Technological aspect factors of Elearning readiness in higher education institutions: Delphi technique. Education and Information Technologies, 24(1), 567-590.

Al-Azawei, A., Parslow, P., and Lundqvist, K. (2016). Barriers and opportunities of e-learning implementation in Iraq: A case of public universities. The International Review of Research in Open and Distributed Learning, 17(5).

Ali, S., Uppal, M.A. and Gulliver, S.R., 2018b. A conceptual framework highlighting e-learning implementation barriers. Information Technology \& People.

Ally, M. (2004). Foundations of educational theory for online learning. Theory and practice of online learning, 2, 15-44.

Almaiah, M. A. (2018). Acceptance and usage of mobile information system services at the University of Jordan. Education and Information Technologies, 23(5), 1873-1895.

Almaiah, M. A., \& Al Mulhem, A. (2019). Analysis of the essential factors affecting intention to use of mobile learning applications: A comparison between universities adopters and non-adopters. Education and Information Technologies, 24(2), 1433-1468.

Almaiah, M. A., \& Alamri, M.M. (2018). Proposing a new technical quality requirement for mobile learning applications. Journal of Theoretical and Applied Information Technology, 96, 19.

Almaiah, M. A., \& Man, M. (2016). Empirical investigation to explore factors that achieve a high quality of mobile learning system based on students' perspectives. Engineering Science and Technology, an International Journal, 19(3), 1314-1320.

Almaiah, M. A., Al-Khasawneh, A., \& Althunibat, A. (2020). Exploring the critical challenges and factors influencing the E-learning system usage during the COVID-19 pandemic. Education and Information Technologies, 1.

Almanthari, A., Maulina, S., \& Bruce, S. (2020). Secondary School Mathematics Teachers' Views on E-learning Implementation Barriers during the COVID-19 Pandemic: The Case of 
Indonesia. Eurasia Journal of Mathematics, Science and Technology Education, 16(7), em1860.

Almanthari, A., Maulina, S., \& Bruce, S. (2020). Secondary School Mathematics Teachers' Views on E-learning Implementation Barriers during the COVID-19 Pandemic: The Case of Indonesia. Eurasia Journal of Mathematics, Science and Technology Education, 16(7), em1860.

Ash K. (2014) 'E-Learning's Potential Scrutinized in Flu Crisis'. Education Week, 282009, 1-13.

Aviram, R., \& Tami, D. (2004). The Impact of ICT on education: the three opposed paradigms, the lacking discourse. Unpublished manuscript, Beer-Sheva University Israel. Disponible en: http://www. eLearning Europa. info/ extras/pdf/ict_impact. $p d f$.

Balanskat, A. (2006). The ICT Impact Report: A review of studies of ICT impact on schools in Europe, European Schoolnet. http://insight. eun. org/shared/data/pdf/impact study. pdf.

Basilaia, G., \& Kvavadze, D. (2020). Transition to online education in schools during a SARS-CoV-2 coronavirus (COVID-19) pandemic in Georgia. Pedagogical Research, 5(4), 1-9.

Basilaia, G., \& Kvavadze, D. (2020). Transition to online education in schools during a SARS-CoV-2 coronavirus (COVID-19) pandemic in Georgia. Pedagogical Research, 5(4), 1-9.

Batara, C., \& Rapat, C. I. (2020). Design and implementation of virtual university based on ict. International Journal of Research-GRANTHAALAYAH, 8(4), 144-152.

Bibeau, R. (1996). Computerized turnkey school. Franco-Quebec action research project.

Board, H. S. R. C., Act, H. S. R. C., \& Strategy, A. C. (2016). A bitter pill: not all students ready for e-learning.

Carliner, S., \& Shank, P. (Eds.). (2016). The e-learning handbook: past promises, present challenges. John Wiley \& Sons.

Clark, R. C., \& Mayer, R. E. (2016). E-learning and the science of instruction: Proven guidelines for consumers and designers of multimedia learning. John Wiley \& Sons.

Dictionary, O. E. (Ed.) (2015). Oxford English Dictionary. Oxford: Oxford University Press.

Doise, W., Mugny, G., James, A. S., Emler, N., \& Mackie, D. (2013). The social development of the intellect (Vol. 10). Elsevier.

Downes, S. (2005). E-learning 2.0. Elearn magazine, 2005(10), 1. 
Ebner, M., Schön, S., Braun, C., Ebner, M., Grigoriadis, Y., Haas, M., ... \& Taraghi, B. (2020). COVID-19 Epidemic as E-Learning Boost? Chronological Development and Effects at an Austrian University against the Background of the Concept of "ELearning Readiness". Future Internet, 12(6), 94.

Eltahir, M. E. (2019). E-learning in developing countries: Is it a panacea? A case study of Sudan. IEEE Access, 7, 9778497792.

Ertmer, P. A. (1999). Addressing first and second-order barriers to change: Strategies for technology integration. ETR\&D, $7(4), 47-61$.

Faherty, L. J., et al. (2019) 'School and preparedness officials' perspectives on social distancing practices to reduce influenza transmission during a pandemic: Considerations to guide future work'. Preventive Medicine Reports, 14(December 2018), 100871. https://doi.org/10.1016/ j.pmedr.2019.100871

Favale, T., Soro, F., Trevisan, M., Drago, I., \& Mellia, M. (2020). Campus Traffic and e-Learning during COVID-19 Pandemic. Computer Networks, 107290.

Germann, T. C., et al. (2019). 'School dismissal as a pandemic influenza response: When, where and for how long?', Epidemics, 28(June), 100348. https://doi.org/10.1016/ j.epidem.2019.100348

Gohiya, P., \& Gohiya, A. (2020). E-learning during COVID 19 Pandemic. DOI: https://doi.org/10.21203/rs.3.rs-29575/v1

Good, T. L., \& Brophy, J. E. (1990). Educational psychology: A realistic approach. Longman/Addison Wesley Longman.

Hall, B. (2000). e-Learning building competitive advantage through people and technology. Online Forbes.com, Special Advertising Section. www.forbes.com/specialsections/ elearning/.

Holmes, B., \& Gardner, J. (2006). E-learning: Concepts and practice. Sage.

Huang, R. H., Liu, D. J., Tlili, A., Yang, J. F., \& Wang, H. H. (2020). Handbook on facilitating flexible learning during educational disruption: The Chinese experience in maintaining undisrupted learning in the COVID-19 outbreak. Beijing: Smart Learning Institute of Beijing Normal University.

Iqbal, M. J., \& Ahmad, M. (2010). Enhancing quality of education through e-learning: The case study of Allama Iqbal Open University. Turkish Online Journal of Distance Education, 11(1), 84-97. 
Keller, C., \& Cernerud, L. (2002). Students' perceptions of elearning in university education. Journal of Educational Media, 27(1-2), 55-67.

Lee, B. C., Yoon, J. O. \& Lee, I. (2009). Learners' acceptance of elearning in South Korea: Theories and results. Computers \& Education, 53(4), 1320-1329.

Liaw, S. S. (2008). Investigating students' perceived satisfaction, behavioral intention, and effectiveness of e-learning: A case study of the Blackboard system. Computers and Education, $51(2), 864-873$.

Malhotra, M. (2020). Learning via Computer-mediated communication During the COVID-19 Lockdown. Thai with ISSN 2320-0693 is a UGC CARE Journal, 19(10), 185-189.

Martín-Rodríguez, Ó., Fernández-Molina, J. C., Montero-Alonso, M. Á., \& González-Gómez, F. (2015). The main components of satisfaction with e-learning. Technology, Pedagogy and Education, 24(2), 267-277.

Mayer, R.E. (2014b). Introduction to multimedia learning. In R. E. Mayer (Ed.), The Cambridge handbook of multimedia learning (2nd ed., pp. 1-24) New York: Cambridge University Press.

Mayes, T., \& De Freitas, S. (2004). Review of e-learning theories, frameworks, and models. JISC e-learning models study report. McGraw-Hill.

Mödritscher, F. (2006). E-learning theories in practice: A comparison of three methods. Journal of Universal Science and Technology of Learning, 28, 3-18.

Mohammadi, H. (2015). Investigating users' perspectives on elearning: An integration of the TAM and IS success model. Computers in human behavior, 45, 359-374.

Nagar, S. (2020). Assessing Students' perception toward elearning and effectiveness of online sessions amid COVID-19 Lockdown Phase in India: An analysis. Thai with ISSN 23200693 is a UGC CARE Journal, 19(13), 272-291.

Naveed, Q. N., Qureshi, M. R. N., Alsayed, A. O., Muhammad, A., Sanober, S. and Shah, A. (2017, November). Prioritizing barriers of E-learning for effective teaching-learning using the fuzzy analytic hierarchy process (FAHP). In 2017 4th IEEE International Conference on Engineering Technologies and Applied Sciences (ICETAS) (pp. 1-8). IEEE.

Nawaz, A., \& Khan, M. Z. (2012). Issues of technical support for elearning systems in higher education institutions. 
International Journal of Modern Education and Computer Science, 4(2), 38.

Negash, S., Whitman, M. E., Woszczynski, A. B., Hoganson, K., \& Mattord, H. (2008). Handbook of distance learning for realtime and asynchronous information technology education (pp. 45-54). Information Science Reference.

Ouadoud, M., Chkouri, M. Y., \& Nejjari, A. (2018). Learning management system and the underlying learning theories: towards new modeling of an LMS. International Journal of Information Science and Technology, 2(1), 25-33.

Ozudogru, F., \& Hismanoglu, M. (2016). Views of freshmen students on foreign language courses delivered via Elearning. Turkish Online Journal of Distance Education, 17(1), 31-47.

Pange, A., \& Pange, J. (2011). Is e-learning based on learning theories? A literature review. World Academy of Science, Engineering and Technology, 56, 62-66.

Radijeng, K. (2010, August). Open access in institutions of higher learning in Botswana. In world library and information congress: 76th IFLA general conference and assembly (pp. 10-15).

Robbins, S.R. (2002, April). The evolution of the learning content management system. www.learningcircuits.org/2002/apr 2002/robbins

Rochester, J.B. (2002). e-Learning as a strategic corporate asset.

Rosenberg, M. J. (2001), E-learning: Strategies for delivering knowledge in the digital age. New York:

Sintema, E. J. (2020). Effect of COVID-19 on the Performance of Grade 12 Students: Implications for STEM Education. Eurasia Journal of Mathematics, Science and Technology Education, 16(7), em1851.

Sułkowski, Ł. (2020). Covid-19 pandemic; recession, virtual revolution leading to de-globalization?.Journal of Intercultural Management, 12(1), 1-11.

Teo, T. (2010). A structural equation modeling of factors influencing student teachers' satisfaction with e-learning. British Journal of Educational Technology, 41, 150-152.

Teo, T. (2014). Preservice teachers' satisfaction with elearning. Social Behavior and Personality: an international journal, 42(1), 3-6.

Ting, D. S. W., Carin, L., Dzau, V., \& Wong, T. Y. (2020). Digital technology and COVID-19. Nature medicine, 26(4), 459-461. 
Vershitskaya, E. R., Mikhaylova, A. V., Gilmanshina, S. I., Dorozhkin, E.M., \& Epaneshnikov, V. V. (2020). Present-day management of universities in Russia: Prospects and challenges of e-learning. Education and Information Technologies, 25(1), 611-621.

Walker, L. (2002, March). e-Learning - Just - in - time. The WriteEdge.www.writeedge.com/articsles/E-learning. asp.

Wang, L.-C. C., \& Bagakas, J. G. (2003). Understanding the dimensions of self-exploration in web-based learning environments. Journal of Research on Technology in Education, 34, 364-376.

Welsh, E. T., Wanberg, C. R., Brown, K. G., \& Simmering, M. J. (2003). E-learning: emerging uses, empirical results, and future directions. International Journal of Training and Development, 7(4), 245-258.

Yusuf, B. N. (2020). Are we Prepared Enough? A Case Study Of Challenges In Online Learning In A Private Higher Learning Institution During The Covid-19 Outbreaks. Advances in Social Sciences Research Journal, 7(5), 205-212.

Zaharah, Z., \& Kirilova, G. I. (2020). Impact of Corona Virus Outbreak Towards Teaching and Learning Activities in Indonesia. SALAM: Jurnal Sosial dan Budaya Syar-i, 7(3). https://doi.org/10.15408/ jobs.v7i3.15104

Zayapragassarazan, Z. (2020). COVID-19: Strategies for Online Engagement of Remote Learners. F1000Research, 9.

Zhou, L., Wu, S., Zhou, M., \& Li, F. (2020). 'School's Out, But Class' On', The Largest Online Education in the World Today: Taking China's Practical Exploration During The COVID-19 Epidemic Prevention and Control As an Example. But Class' On', The Largest Online Education in the World Today: Taking China's Practical Exploration During The COVID-19 Epidemic Prevention and Control As an Example (March 15, s 